\title{
PENGEMBANGAN DESAIN POJOK BACA DI SDN 060925 MEDAN AMPLAS
}

\author{
${ }^{1}$ Nurlatifah, ${ }^{2}$ Hidayat \\ ${ }^{1}$ SDN 060925 Medan Amplas , ${ }^{2}$ Universitas Muslim Nusantara Al Washliyah Medan \\ hidayat@umnaw.ac.id
}

\begin{abstract}
Abstrak
Penelitian ini bertujuan untuk mengembangkan desain pojok baca di SD Negeri 060925 Medan Amplas. Masalah dalam penelitian ini antara lain adalah kurangnya minat baca siswa, banyak siswa yang tidak suka membaca, padahal di kelas tingkat tinggi seperti itu menuntut siswa harus lebih banyak membaca karena siswa pada umumnya sudah harus memahami soal cerita. Kurangnya alternatif dan media yang digunakan pada saat proses belajar mengajar. Siswa lebih senang bermain daripada membaca buku, sehingga pemahaman siswa terhadap pembelajaran juga tergolong rendah. Model penelitian ini menggunakan model pengembangan ADDIE (Analysis, Design, Development, Implementation, and Evaluation). Proses pengembangan pojok baca untuk siswa SD dilakukan dengan mengadopsi prosedur pengembangan ADDIE. Prosedur pengembangan ini disesuaikan dengan pedoman pengembangan bahan ajar sehingga pada setiap tahapan terdiri atas beberapa proses. Hasil penelitian menunjukkan bahwa dengan adanya pojok baca menampilkan keindahan ruang, dan minat baca siswa yang baik.
\end{abstract}

Kata kunci : Disain Pojok Baca

\begin{abstract}
This study aims to develop a reading corner design at SD Negeri 060925 Medan Amplas. Problems in this study include the lack of interest in reading among students, many students do not like to read, even though in such high-level classes, students must read more because students in general have to understand story problems. Lack of alternatives and media used during the teaching and learning process. Students prefer to play rather than read books, so that students' understanding of learning is also low. This research model uses the ADDIE development model (Analysis, Design, Development, Implementation, and Evaluation). The process of developing a reading corner for elementary students is carried out by adopting the ADDIE development procedure. This development procedure is adjusted to the guidelines for developing teaching materials so that at each stage it consists of several processes. The results showed that the presence of a reading corner showed the beauty of the space, and students' interest in reading was good.
\end{abstract}

Keywords: Reading Corner Design 


\section{PENDAHULUAN}

http://jurnal.umt.ac.id/index.php/IJOEE

Minat baca merupakan faktor utama untuk meningkatkan kualitas sumber daya manusia khususnya pemerintah dalam menunjang keberhasilan program pendidikan nasional yang mencerdaskan kehidupan bangsa. Peningkatan kualitas sumber daya manusia sangat diperlukan untuk menghadapi persaingan dalam berbagai hal. Oleh sebab itu, semakin tinggi minat baca masyarakat maka semakin tinggi juga sumber daya manusia tersebut dan dapat tumbuh menjadi bangsa yang maju. Minat baca dapat diperoleh mulai usia dini yaitu melalui kebiasaan melakukan kegiatan membaca. Dengan banyak membaca maka akan memiliki kemampuan berbicara yang sistematis dan logis dengan alur pikiran yang runtut.

Membaca merupakan salah satu dari ketrampilan berbahasa. Membaca merupakan faktor penting dalam sebuah proses pembelajaran di sekolah. Dengan membaca, seseorang memperoleh informasi. Informasi dari bahan bacaan dari berbagai media. Membaca juga menjadi salah satu sarana untuk berkomunikasi. Membaca merupakan komunikasi dari pemikiran antara penulis dan pembaca. Jadi dengan membaca, siswa dapat mengunduh pengetahuan yang disediakan penulis. Semakin sering membaca, semakin banyak pengetahuan yang dimiliki.

Di Indonesia, minat membaca masyarakat saat ini masih memprihatinkan, berdasarkan data yang dikeluarkan oleh UNESCO tahun 2018 menyebutkan Indonesia urutan kedua dari bawah soal literasi dunia, artinya minat baca sangat rendah. Menurut data UNESCO, minat baca masyarakat Indonesia sangat memprihatinkan, hanya $0,001 \%$. Artinya, dari 1,000 orang Indonesia, cuma 1 orang yang rajin membaca. Fakta kedua, 60 juta penduduk Indonesia memiliki gadget, atau urutan kelima dunia terbanyak kepemilikan gadget. Lembaga riset digital marketing Emarketer memperkirakan pada 2018 jumlah pengguna aktif smartphone di Indonesia lebih dari 100 juta orang. Dengan jumlah sebesar itu, Indonesia akan menjadi negara dengan pengguna aktif smartphone terbesar keempat di dunia setelah Cina, India, dan Amerika.

Hasil observasi awal di SDN 060925, diperoleh informasi bahwa, minat membaca siswa di SDN 060925 masih kurang, banyak siswa yang tidak suka membaca, padahal di kelas tingkat tinggi seperti itu menuntut siswa harus lebih banyak membaca karena siswa pada umumnya sudah harus memahami soal cerita. Hal ini disebabkan karena kurangnya alternatif dan media yang digunakan pada saat proses belajar mengajar. Banyak guru hanya menyuruh anak membaca saja tanpa memberi arahan untuk membuat sebuah keterampilan yang membuat mereka termotivasi dalam membaca. 
Pembelajaran selama ini di SDN 060925 Medan masih berpusat pada guru sehingga banyak siswa yang bosan dalam belajar. Selain itu, rendahnya minat baca, seperti diketahui bahwa siswa lebih senang bermain daripada membaca buku, sehingga pemahaman siswa terhadap pembelajaran juga tergolong rendah. Oleh karena itu, peneliti menawarkan solusi untuk meningkatkan minat baca siswa yaitu melalui pengembangan media pojok baca. Pojok baca merupakan sebuah media yang dapat memanfaatkan ruang sebagai budaya untuk meningkatkan minat baca. Pojok baca memiliki kelebihan untuk bisa ditempatkan dimanapun, bisa di ruangan kelas, bisa di depan kelas dan dengan media apapun, yang terpenting adalah bisa diakses dengan mudah oleh para siswa dan guru, bahkan orang tua. Bahan dasar yang digunakan dalam media pojok baca adalah bahan sederhana sehingga tidak membutuhkan dana yang terlalu besar. Nugroho dkk (2016) menyatakan pojok baca meningkatkan minat baca. Pojok baca dimanfaatkan untuk membaca disaat siswa ada waktu luang dan memberikan suasana baru di kelas (Husna, 2020).

\section{Pengertian Membaca}

Membaca adalah saat pembaca menggerakkan mata sepanjang baris-baris tulisan dalam sebuah teks bacaan. Membaca melibatkan aktivitas mental yang dapat menjamin pemerolehan pemahaman menjadi maksimal. Membaca bukan hanya sekadar menggerakkan bola mata dari margin kiri ke kanan tetapi jauh dari itu, yakni aktivitas berpikir untuk memahami tulisan demi tulisan.

Pendidikan di Sekolah Dasar bertujuan untuk memberikan bekal pengetahuan, kemampuan membaca, menulis dan menghitung pada siswa. Bekal pengetahuan dan kemampuan yang dimiliki tersebut akan sangat berperan membantu siswa dalam mengikuti pendidikan selanjutnya serta dalam kehidupannya di masyarakat kelak. Membaca juga merupakan jembatan dalam kehidupan di era globalisasi ini. Minat membaca merupakan suatu kecenderungan kepemilikan keinginan atau ketertarikan yang kuat disertai usaha-usaha yang terus menerus pada diri seseorang terhadap kegiatan membaca yang dilakukan secara terus menerus dan diikuti rasa senang tanpa paksaan, atas kemauan sendiri atau dorongan dari luar sehingga seseorang tersebut mengerti atau memahami apa yang dibacanya.

\section{Desain Pojok Baca}

Pojok baca merupakan pemanfaatan sudut ruang kelas sebagai tempat kolehsi buku dari para siswa di tiap-tiap kelas. Penerapan media pojok baca di SD Negeri 060925 Medan Amplas diharapkan akan merangsang peserta didik untuk lebih berminat membaca dan memiliki daya pikir 
yang baik. Pemanfaatan sudut ruang kelas untuk dijadikan pojok baca juga sebagai penunjang dari perpustakaan sekolah. Selain peserta didik membaca, meminjam, dan menjelajah sumber ilmu dari perpustakaan sekolah, peserta didik juga bisa memanfaatkan pojok baca di kelas mereka masingmasing.

Pojok baca didesain dengan tampilan yang menarik sehingga peserta didik lebih berminat untuk membaca buku tersebut. Bahan dasar yang digunakan untuk membuat pojok baca menggunakan alat dan bahan yang sederhana sehingga tidak membutuhkan dana yang terlalu besar. Bahan dasar yang digunakan yaitu meja yang tidak terpakai yang ada di belakang kelas. Meja tersebut dapat dimanfaatkan sebagai pojok baca untuk meminimalisir pengeluaran dan memanfaatkan bahan yang tidak terpakai di kelas.

Desain tatanan pojok baca yang dibuat dengan desain minimalis dengan warna-warni yang akan mewarnai sudut kelas agar membuat kelas lebih berwarna. Meja tersebut akan diberikan taplak untuk menjaga kebersihan meja tersebut. Beberapa contoh pojok baca :

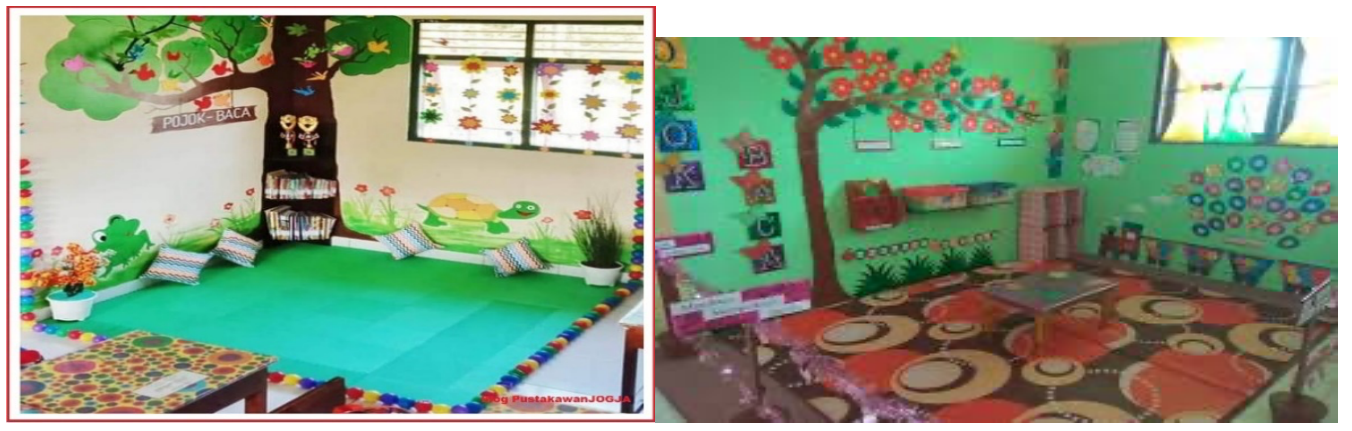

Gambar 1. Pojok Baca

Sumber: https://pustakawanjogja.blogspot.com/

Pojok baca pada gambar di atas ditempatkan di dalam ruang kelas. Ukuran pojok baca disesuaikan dengan ruangan yang ada, jika kelas berukuran besar, maka pojok baca dapat dibuat seperti pada gambar di atas dan jika ruangan yang tersedia lebih lebih kecil dapat disesuaikan kebutuhannya.

\section{METODE PENELITIAN}

Tahap evaluasi merupakan tahap penilaian terhadap pengembangan pojok baca dilihat dari komponen kelayakan isi, penyajian, kesesuaian, dan kegrafikaan untuk mengetahui kualitas pojok baca yang dikembangkan. Selain itu, pada tahap ini dilakukan pula penilaian terhadap efektivitas 
pojok baca dalam memfasilitasi pencapaian literasi siswa.

http://jurnal.umt.ac.id/index.php/lJOEE

Teknik analisis data yang digunakan oleh peneliti adalah jenis data kualitatif dan data kuantitatif. Peneliti melakukan dengan mengolah data yang telah terkumpul. Data yang sudah terkumpul peneliti olah secara kualitatif dan kuantitatif.

1. Data Kualitatif

Data kualitatif diperoleh dari hasil observasi, angket pra-penelitian guru dan dokumentasi. Hasil observasi dideskripsikan sesuai dengan panduan observasi yang digunakan oleh peneliti.Angket pra-penelitian guru diolah sesuai dengan pendapat yang sudah dituliskan oleh guru serta dokumentasi dalam bentuk foto yang diambil ketika peneliti melaksanakan uji coba produk.

2. Data Kuantitatif

Data kuantitatif berupa perhitungan data yang diperoleh dari angket pra-penelitian serta hasil validasi oleh ahli dan guru terhadap produk yang sudah dihasilkan. Analisis data dilakukan dengan tujuan untuk memperbaiki kekurangan dan kelemahan produk yang sudah dikembangkan oleh peneliti.

\section{Hasil Pengembangan Produk Awal}

Sesuai dengan model pengembangan ADDIE, prosedur yang dilakukan dalam penelitian pengembangan meliputi 5 tahap, yaitu: (1) analysis, (2) design, (3) development, (4) implementation, dan (5) evaluation. Model ADDIE ini sebelumnya juga digunakan oleh peneliti lain yang dapat menguatkan penelitian ini. Merujuk pada model pengembangan pojok baca, berikut ini merupakan penjelasan tahapan-tahapan yang telah dilakukan dalam pengembangan desain pojok baca penelitian ini.

\section{a. Tahap Analisis (Analysis)}

Hal-hal yang dianalisis meliputi kebutuhan siswa dan kurikulum yang bersesuaian dengan materi. Proses yang dilakukan pada tahap analisis dijelaskan sebagai berikut.

1) Analisis kebutuhan siswa

Sebagai pengembangan dari gerakan literasi sekolah, guru haruslah kreatif dalam menciptakan budaya literasi di dalam kelas. Salah satu caranya adalah dengan menciptakan pojok baca di dalam kelas. Hal ini tentu dibuat dengan adanya kreativitas guru. Pojok baca bertjuan untuk meningkatkan kecintaan dan minat siswa terhadap membaca buku. Pada pojok 
http://jurnal.umt.ac.id/index.php/lJOEE

baca tersebut disediakan buku-buku tentang pendidikan serta ilmu pengetahuan, serta hasil karya siswa sehingga menambah keunikan dan keragaman dalam pojok baca tersebut.

Berdasarkan hasil observasi, diperoleh informasi bahwa, minat membaca siswa masih kurang, banyak siswa yang tidak suka membaca, padahal di kelas tingkat tinggi seperti itu menuntut siswa harus lebih banyak membaca karena siswa pada umumnya sudah harus memahami soal cerita. Hal ini disebabkan karena kurangnya alternatif dan media yang digunakan pada saat proses belajar mengajar. Banyak guru hanya menyuruh anak membaca saja tanpa memberi arahan untuk membuat sebuah keterampilan yang membuat mereka termotivasi dalam membaca. Pembelajaran selama ini masih berpusat pada guru sehingga banyak siswa yang bosan dalam belajar.

Selain itu, rendahnya minat baca siswa, seperti diketahui bahwa siswa lebih senang bermain daripada membaca buku, sehingga pemahaman siswa terhadap pembelajaran juga tergolong rendah

Sementara itu, pada kurikulum 2013 siswa dituntut untuk memiliki kemampuan menelaah dan memahami tingkat tinggi, dimana memerlukan keterampilan membaca memahami. Sehingga perlu adanya proses menggalakkan minat baca di kalangan siswa.

Dari kondisi tersebut, maka peneliti memandang perlu untuk dikembangkan pojok baca karena mereka memasuki jenjang persiapan kelulusan.

Sehingga diharapkan di kemudian hari siswa terbiasa membaca dan menjadikan membaca sebagai sebuah kesenangan bagi siswa.

2) Analisis Kurikulum

Analisis kurikulum dibutuhkan untuk menentukan bahan bacaan yang diperlukan oleh siswa, sehingga ketersediaan bahan bacaan menjadi bahan bacaan yang bermanfaat dan sesuai dengan rentang usia dan kurikulum yang mereka pelajari.

Materi yang disajikan dalam bahan bacaan berdasarkan pada Kompetensi Inti dan Kompetensi Dasar yang bersesuaian dengan Kurikulum 2013. Kompetensi Inti dan Kompetensi Dasar yang mencakup keseluruhan pelajaran, sehingga bahan bacaan sesuai dengan kebutuhan kurikulum dan kebutuhan siswa. Bahan bacaan yang dipilih berupa ensiklopedia IPA, beberapa buku sejarah, Atlas/gambaran permukaan bumi. Hasil analisis kurikulum ini kemudian adalah untuk menentukan buku dan bahan bacaan yang sesuai dengan 
kurikulum yang dipelajari oleh siswa

http://jurnal.umt.ac.id/index.php/IJOEE

\section{b. Tahap Desain (Design)}

Hasil tahap analisis dijadikan sebagai dasar dalam membuat desain pojok baca. Halhal yang dilakukan pada tahap desain yaitu menyusun kebutuhan bahan bacaan, menentukan struktur pojok baca, menyusun instrumen penelitian, dan validasi instrumen penelitian oleh ahli. Proses yang dilakukan pada tahap desain diuraikan sebagai berikut:

1) Menyusun kebutuhan bahan bacaan

Penyusunan peta kebutuhan bahan bacaan dilakukan dengan memperhatikan kebutuhan siswa, kebutuhan kurikulum, SK dan KD mata pelajaran. Kebutuhan bahan bacaan disusun untuk memudahkan peneliti dalam mengurutkan buku-buku yang akan disajikan pada pojok baca. Pada penelitian ini bahan bacaan yang menjadi pilihan adalah buku-buku yang berkaitan dengan bahan belajar siswa, sehingga dapat mendukung materi yang sesuai dengan yang dipelajari oleh siswa. Indikator pojok baca adalah sebagai berikut:

a. Perencanaan pembuatan pojok baca

b. Keindahan

c. Kesesuaian

d. pelaksanaan

e. Menetapkan struktur desain pojok baca

Struktur desain pojok baca dapat ditetapkan dengan memuat hal-hal apa saja yang akan diposisikan di dalam pojok. Seperti peletakan buku, dekorasi, pemilihan warna dekorasi.

\section{c. Tahap Pengembangan (Development)}

Pojok baca yang telah didesain, selanjutnya divalidasi terhadap 2 validator ahli materi. Penentuan subyek ahli mempunyai kriteria yaitu berpengalaman dibidangnya dan berpendidikan minimal S2. Instrumen validasi memakai skala Likert. Tujuan validasi ahli materi yakni mengetahui kesesuaian, kebenaran dan urutan. Penilaian validasi ahli materi pada pojok baca yang dikembangkan terdiri dari 2 ahli di universitas, hasil validasi pojok baca masuk dalam kategori baik dengan melakukan revisi sebanyak dua kali.

\section{d. Tahap Implementasi (Implemetation)}

Pada tahap implementasi, pojok baca ditunjukkan kepada guru untuk dapat digunakan di dalam kelas. Sehubungan adanya pandemi Covid-19 yang melanda Indonesia dan juga 
mempengaruhi kegiatan belajar mengajar di sekolah. Sehingga implementasi penggunaan/penerapan pojok baca dilakukan guru melalui daring (dalam jaringan).

Melalui proses belajar daring, dan berdasarkan kuesioner yang dilakukan terhadap guru dapat diketahui bahwa pembelajaran dapat dilakukan dengan baik penggalakan rasa senang siswa terhadap membaca dilakukan secara daring dengan memberikan bahan bacaan lain selain pelajaran untuk dibaca siswa, kemudian siswa diminta menceritakan kembali bacaan yang mereka baca.

\section{e. Evaluasi (Evaluation)}

Tahap evaluasi menunjukkan bahwa pojok baca yang telah divalidasi dan telah di implementasikan dengan memperkenalkan pojok baca oleh guru kelas dalam pembelajaran daring kemudian peneliti mendeskripsikan hasil evaluasi berdasarkan validasi ahli dan hasil implementasi yang dilakukan guru kepada siswa melalui kegiatan pembelajaran secara daring.

\section{Pembuatan Instrumen Penelitian}

Instrumen yang dibuat dalam penelitian ini terdiri atas instrumen lembar observasi pojok baca. Pembuatan instrumen penilaian pojok baca mengacu pada kriteria bahan ajar yang baik menurut Badan Standar Nasional Pendidikan (BSNP). Instrumen ini terdiri dari dua macam, yaitu instrumen penilaian pojok baca oleh pegiat literasi, dan instrumen penilaian pojok baca oleh guru. Instrumen tersebut berupa lembar observasi dengan skala Likert. Instrumen tersebut digunakan untuk menilai kualitas pojok baca yang dikembangkan berdasarkan komponen kelayakan yang telah disusun sebelumnya.

\section{Hasil Uji Coba Produk}

Hasil uji coba produk pojok baca menunjukkan bahwa bahan bacaan yang disediakan di pojok baca sudah baik, hal ini sesuai dengan penilaian pada lembar validasi bahan ajar. Akan tetapi, ada beberapa revisi terkait bahan ajar tersebut, adapun yang menjadi bahan pertimbangan perbaikan bahan ajar adalah:

a. Bahan bacaan kurang memadai, ada baiknya bahan bacaan disesuaikan dengan kebutuhan dan kurikulum yang digunakan siswa.

b. Kurangnya pajangan hasil karya siswa yang dapat menjadi motivasi bagi siswa lain agar lebih menyukai membaca 
c. Lebih memperhatikan variasi warna pada pojok baca agar lebih menarik minat siswa untuk membaca.

\section{HASIL DAN PEMBAHASAN}

Pengembangan pojok baca ditujukan untuk memfasilitasi pencapaian siswa dalam bidang literasi. Dalam penelitian ini, pojok baca dikatakan berhasil jika semakin banyak siswa yang menyelesaikan bahan bacaan yang tersedia di pojok baca, dan terdapat umpan balik yang dilakukan siswa seperti menceritakan kembali apa yang telah mereka baca. Sejatinya, pojok baca merupakan salah satu langkah guru untuk memfasilitasi siswa di dalam kelas, dan membantu adanya gerakan membaca oleh siswa di kelas. Sehingga membaca dapat menjadi budaya dan kebiasaan baik dalam kehidupan siswa.

\section{Revisi Produk}

Saran atau komentar mengenai pojok baca yang dilihat dari perolehan hasil validasi. Saran atau komentar tersebut digunakan peneliti sebagai penunjuk untuk merevisi pojok baca yang dikembangkan. Berdasarkan instrumen validasi yang diserahkan peneliti terhadap validator didapat hasil agar dilakukan revisi terhadap bagian yang perlu untuk diperbaiki tentang bahan bacaan dan kesesuaian bahan bacaan dengan kurikulum yang digunakan siswa saat ini.

\section{Sebelum revisi}

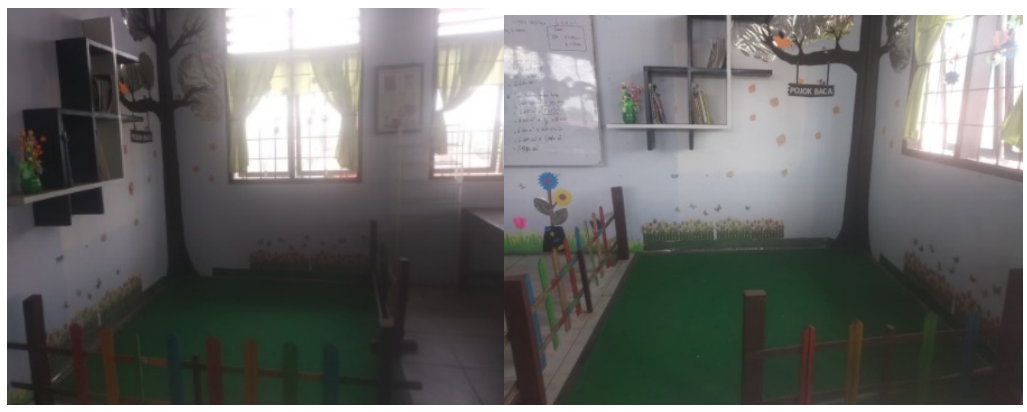

Pada gambar di atas tampak penyediaan bahan bacaan di ruang pojok baca masih kurang, bahan bacaan belum sesuai dengan kebutuhan siswa, warna dan hiasan kurang yang menarik.

Setelah telaah pakar dilakukan penyempurnaan dan revisi, dengan hasil sebagai berikut: 
Setelah revisi

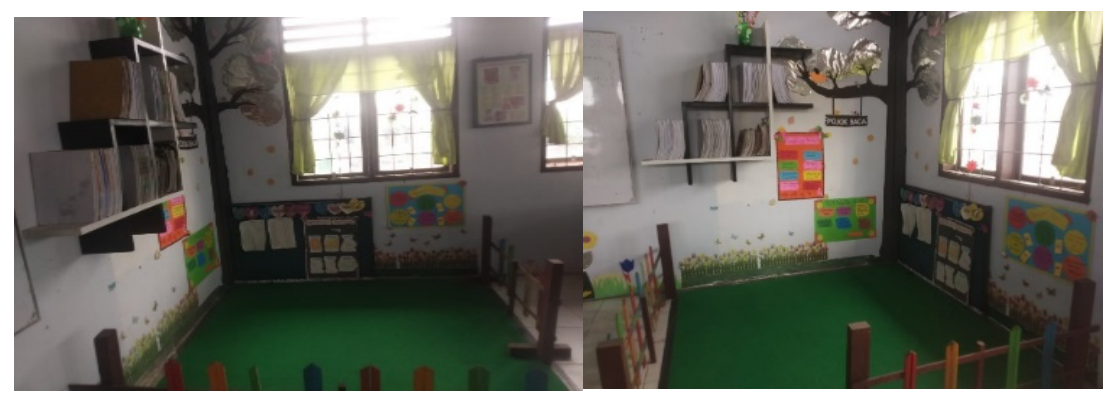

Dengan memperhatikan saran dari pakar alat dan bahan ditambah, penambahan warna dan hiasan, dan penyesuaian kebutuhan belajar siswa.

\section{KESIMPULAN DAN HASIL}

Berdasarkan hasil penelitian dan pembahasan yang telah diuraikan, dapat disimpulkan beberapa hal sebagai berikut.

1. Pengembangan pojok baca untuk siswa SD dilakukan dengan mengadopsi prosedur pengembangan $A D D I E$ yang terdiri atas tahap analisis (analysis), tahap desain (design), tahap pengembangan (development), tahap implementasi (implementation), dan tahap evaluasi (evaluation). Prosedur pengembangan ini disesuaikan dengan pedoman pengembangan bahan ajar sehingga pada setiap tahapan terdiri atas beberapa proses. Proses pada tahap analisis meliputi: a) analisis kebutuhan siswa dan b) analisis kurikulum. Proses pada tahap desain meliputi: a) penyusunan peta kebutuhan pojok baca; b) penetapan struktur desain pojok baca; c) pembuatan instrumen penelitian; dan d) validasi instrumen penelitian.

2. Kualitas pojok yang dikembangkan berdasarkan perencanaan pembuatan pojok baca, keindahan, kesesuaian, dan pelaksanaan pojok baca menunjukkan kriteria baik

\section{Saran}

Beberapa hal yang dapat dijadikan sebagai saran dari penelitian yang telah dilakukan sebagai berikut:

1. Pojok Baca yang dikembangkan dalam penelitian ini telah memenuhi kriteria baik sehingga dapat dijadikan salah satu alternatif dalam memfasilitasi siswa dengan sumber belajar tambahan dan guru sebagai penunjang kegiatan pembelajaran agar siswa semakin giat dalam pengembangan literasi.

2. Pojok baca yang dikembangkan hanya untuk memfasilitasi pencapaian literasi secara umum. Hal ini dapat dijadikan sebagai acuan bagi peneliti lain yang ingin mengembangkan pojok baca 
sebagai sarana peningkatan budaya literasi dan membiasakan siswa membaca dengan efektivitas pencapaian literasi pada level tertentu.

\section{DAFTAR PUSTAKA}

Abdurrahman, Abror. 2018. Psikologi Pendidikan. Yogyakarta: Tiara Wacana

Devega, Evita. 2017. Teknologi Masyarakat Indonesia: Malas Baca tapi Cerewet di Medsos. Laman: (https://www.kominfo.go.id/content/detail/10862/teknologi-masyarakat-indonesia-malas-baca-tapicerewet-di-medsos/) diakses pada 2 Februari 2021

Farida Rahim. 2008. Pengajaran Membaca di Sekolah Dasar. Jakarta: Bumi Aksara

Fauziyah, Risqi, Ika, dkk. 2010. Faktor-Faktor yang Mempengaruhi Minat Mahasiswa PGSD UPP Tegal Untuk Membaca Buku di Perpustakaan PGSD UPP Tegal. Laporan Penelitian Institusional Universitas Negeri Semarang

Hernowo, 2010. Mengingat Makna: Kiat-kiat Ampuh untuk Melejitkan Kemauan plus Kemampuan Membaca dan Menulis Buku. Bandung: Penerbit Kaifa

Husna, Zurni. 2020. Pemanfaatan Pojok Baca Kelas Dalam Peningkatan Gerakan Literasi Sekolah. Jurnal Ecodunamika Vol. 3 No. 2. https://ejournal.uksw.edu/ecodunamika/article/view/3374

KBBI. 2014. Kamus Besar Bahasa Indonesia (KBBI) online. Available at $: \underline{\text { http://kbbi.web.id/pusat }}$ diakses pada 23 Januari 2021.

Mikarsa, Hera Lestari, dkk. 2009. Pendidikan Anak SD. Jakarta: Universitas Terbuka

Muhibbinsyah. 2019. PSikologi Pendidikan dengan Pendekatan Baru. Bandung: Remaja Rosdakarya Nugroho, Alfian Handina; Puspitasari, Ratna; dan Puspitasari Euis. 2016. Implementasi Gemar Membaca Melalui Program Pojok Baca dalam Mata Pelajaran IPS pada Siswa Kelas VIII di SMPN 2 Sumber. EDUEKSOS: Jurnal Pendidikan Sosial dan Ekonomi. Vol 5 No. 2. Hal 187 - 206. DOI: 10.24235/edueksos.v5i2.1167

Puji, Santosa. 2009. Materi dan Pembelajaran Bahasa Indonesia SD. Jakarta: Universitas Terbuka Rahim, Farida. 2008. Pengajaran Membaca di Sekolah Dasar. Jakarta: Bumi Aksara.

Ratnasari, Yunita. 2017. Pengaruh Pergaulan Teman Sebaya terhadap Minat Baca Siswa Kelas V SD Negeri Bojongsari I Kabupaten Purbalingga. Skripsi. Yogyakarta: FIP

Widoyoko, Eko Putro. 2012. Evaluasi Program Pembelajaran. Yogyakarta: Pustaka Pelajar Winkel. 2015. Psikologi Pengajaran. Yogyakarta: Media Abadi. 